\title{
Residual Effect of Segregated and Unsegregated Urban Solid Waste Compost on Yield and Nutrient Uptake by Cowpea (Vigna unguiculata L.)
}

\author{
Roohi*, H.C. Prakasha and H.M. Meena
}

Department of Soil Science and Agricultural Chemistry, University of Agricultural Sciences, Gandhi Krishi Vignana Kendra, Bangalore-560065, Karnataka, India

*Corresponding author

\section{Keywords \\ Residual effect, Segregated and unsegregated urban Solid waste compost, Cowpea, Yield and nutrients uptake \\ Article Info \\ Accepted: 12 July 2018 Available Online: 10 August 2018}

\section{A B S T R A C T}

A pot experiment was conducted during kharif-2016 at Department of Soil Science and Agricultural Chemistry, University of Agricultural Sciences, Bangalore (Karnataka) to study the residual effect of segregated and unsegregated urban solid waste compost on yield and nutrient uptake by cowpea (Vigna unguiculata L.). The experiment was laid out under Randomized complete block design with three replication and eleven treatments. Among the treatments, the application of 100 per cent NPK + segregated urban solid waste compost $\left(10 \mathrm{t} \mathrm{ha}^{-1}\right)$ significantly increased the growth parameters (number of branches plant $^{-1}$, number of leaves plant ${ }^{-1}$, leaf area, pod weight plant ${ }^{-1}$, pod length and nodule count), yield and uptake of nutrients (macro and secondary nutrients) by grain and haulm of cowpea as compared to application of chemical fertilizer alone. However, micronutrients uptake was recorded significantly higher in treatment which received 100 per cent NPK + unsegregated urban solid waste compost @ $10 \mathrm{t} \mathrm{ha}^{-1}$.

\section{Introduction}

Pulses are major source of protein for vegetarian which is considered as poor man's protein. Besides an important source of protein content, pulses also improves the soil health and mitigates climate changes. Among the pulses, cowpea is important leguminous crop which is extensively grown in arid and semiarid region of India. It contains 20-25\% protein and also has ability to fix atmospheric nitrogen in soil in association with symbiotic bacteria under favourable conditions (Yadav, 1986). In Karnataka, the productivity of cowpea is low $\left(420 \mathrm{~kg} \mathrm{ha}^{-1}\right)$ as compared to the national productivity of $567 \mathrm{~kg} \mathrm{ha}^{-1}$. The major constraint of low productivity in Indian agriculture is imbalanced supply of nutrient. In context of sustainable agriculture and soil health, the combine application of organic and inorganic fertilizer is the suitable approach to improve soil nutrients and crops productivity (Nigussie et al., 2015).

In modern intensive agriculture, the potential supply of nutrients from soil is not adequate to sustain higher yield and thus external application of nutrient from inorganic and organic sources is inevitable. The addition of urban solid waste compost to soil allows the 
reduction of the applied levels of chemical fertilizer and may increase the efficacy of chemical fertilizers. Therefore, the use of MSW compost is gradually increasing in agricultural areas. MSW compost application contributes soil organic matter is utilized scientifically through segregation and composting results in mitigating environment pollution. Segregation of urban solid waste compost able to reduce heavy metal contamination and maintain the quality of compost which helps to improve the growth and parameters of crops. Organic matter on decomposition increased the efficiency of nutrients and has long lasting effect of compound produced on crop yield and soil properties (Eghball et al., 2004). Keeping these points in view, the present investigation was carried out with an objective yield and uptake of nutrient by cowpea (Vigna unguiculata L.) as influenced by residual segregated and unsegregated urban solid waste compost.

\section{Materials and Methods}

A pot experiment was conducted during kharif- 2016 using cowpea (Vigna unguiculata) variety IT-38956-1 as a test crop. In the previous year (kharif -2015), the finger millet crop was taken as a first crop in the pot $\left(8 \mathrm{~kg}\right.$ soil pot $\left.^{-1}\right)$ for study and the experimental soil was treated with segregated, unsegregated compost and FYM along with 100,50 and $50 \mathrm{~kg} \mathrm{~N}, \mathrm{P}_{2} \mathrm{O}_{5}$ and $\mathrm{K}_{2} \mathrm{O}$ ha $^{-1}$, respectively. Segregated and unsegregated compost were prepared using drum composting method. Segregated compost contain organic urban solid waste such as vegetables, fruits, flower, dry leaves etc. and unsegregated compost contains organic and inorganic urban solid waste without separation. The compost was ready within 7580 days using microbial culture. Segregated compost has less concentration of heavy metals as compared to unsegregated compost.
The chemical composition of segregated, unsegregated urban solid waste compost and Farm Yard Manure (FYM) is presented in Table 1.

The experiment was laid out under Randomized Complete Block design with eleven treatments and was replicated thrice. The residual treatments were $\mathrm{T}_{1}: 100 \%$ NPK + FYM @ 10 t ha $^{-1}$ (Package of Practice); $\mathrm{T}_{2}$ : segregated compost @ $10 \mathrm{t}$ ha ${ }^{-1} ; \mathrm{T}_{3}$ : unsegregated compost @10 t ha ${ }^{-1} ; \mathrm{T}_{4}: \mathrm{FYM}$ @ $10 \mathrm{t} \mathrm{ha}^{-1} ; \mathrm{T}_{5}: 100 \% \mathrm{NPK}+$ segregated compost; $\mathrm{T}_{6}: 100 \%$ NPK + unsegregated compost; $\mathrm{T}_{7}: \mathrm{T}_{2}+50 \% \mathrm{NPK} ; \mathrm{T}_{8}: \mathrm{T}_{3}+50 \%$ $\mathrm{NPK} ; \mathrm{T}_{9}: \mathrm{T}_{4}+50 \% \mathrm{NPK} ; \mathrm{T}_{10}: 50 \%$ NPK; $\mathrm{T}_{11}$ : $100 \%$ NPK.

After experimental preparations, initial soil samples were collected to analyze initial soil properties. The soil samples were analyzed for $\mathrm{pH}$, electrical conductivity, organic carbon, available nitrogen, phosphorus, potassium, calcium, magnesium and sulphur. The experimental soil was found acidic with $\mathrm{pH}$ (5.96), EC $\left(0.11 \mathrm{dSm}^{-1}\right)$ and organic carbon ( 0.36 per cent). The available nitrogen was low (194.12 $\left.\mathrm{kg} \mathrm{ha}^{-1}\right)$, medium in available $\mathrm{P}_{2} \mathrm{O}_{5}\left(35.36 \mathrm{~kg} \mathrm{ha}^{-1}\right)$ and low in available $\mathrm{K}_{2} \mathrm{O} \quad\left(87.6 \quad \mathrm{~kg} \quad \mathrm{ha}^{-1}\right)$. The exchangeable calcium [2.84 cmol $\left.\left(\mathrm{p}^{+}\right) \mathrm{kg}^{-1}\right]$, exchangeable magnesium $\left[1.32 \mathrm{cmol}\left(\mathrm{p}^{+}\right)\right.$ $\left.\mathrm{kg}^{-1}\right]$ and available sulphur content $(0.22 \mathrm{~kg}$ $\mathrm{ha}^{-1}$ ) were found higher. After harvesting of finger millet, cowpea was grown in the same experimental soil in pots without disturbing the treatments to study residual effect of urban solid waste compost.

Growth and yield parameters of cowpea such as plant height, number of leaves plant ${ }^{-1}$, number of branches plant ${ }^{-1}$, leaf area, nodule number, root biomass plant ${ }^{-1}$, number of pods plant $^{-1}$, pod length, number of grains $\operatorname{pod}^{-1}$, test weight and pod weight plant ${ }^{-1}$ haulm were recorded at harvest of cowpea. Grain and 
haulm yield of cowpea were recorded in each pot and expressed as $\mathrm{g} \mathrm{pot}^{-1}$.

The grain and haulm samples of cowpea were grind and digested to measure content of $\mathrm{N}$ by Micro Kjeldahl method (Jackson, 1973), P by Vanado-molybdophosphoric acid (Jackson, 1973), K by flame photometer (Black, 1965), $\mathrm{Ca}$ and $\mathrm{Mg}$ by Versenate titrimetry method (Jackson, 1973) and S by Turbidimetry method (Jackson, 1973). The micronutrients in the grain and haulm of cowpea were analyzed using Atomic absorption spectrophotometry (Lindsay and Norwell, 1978). The nutrients uptake by cowpea was calculated from their contents in the plants multiplied by grain and haulm yield and expressed in $\mathrm{g} \mathrm{plant}^{-1}$ or $\mathrm{mg}_{\mathrm{plant}}{ }^{-1}$.

\section{Statistical analysis}

The data obtained from the study were subjected to statistical analysis of variance method at 5 per cent level of significance as per the procedure given by Sundaraj et al., (1972).

\section{Results and Discussion}

\section{Growth and yield attributes of cowpea}

The application of segregated and unsegregated USW compost along with chemical fertilizer increased the growth and yield attributes viz., plant height, number of leaves plant ${ }^{-1}$, number of branches plant ${ }^{-1}$, leaf area, nodule number, root biomass plant ${ }^{-1}$, number of pods plant ${ }^{-1}$, pod length, number of grains $\operatorname{pod}^{-1}$, test weight and pod weight plant ${ }^{1}$ at harvest of cowpea (Table 2 and 3). There was no significant difference noticed in case of growth parameters viz., plant height $(\mathrm{cm})$ and root biomass plant $^{-1}$ whereas the significant difference was observed in case of number of branches plant ${ }^{-1}$, number of leaves plant $^{-1}$, leaf area, pod length and nodule number. The application of 100 per cent NPK + segregated compost $\left(\mathrm{T}_{5}\right)$ significantly increased the growth and yield parameters of cowpea followed by 100 per cent NPK + unsegregated compost $\left(\mathrm{T}_{6}\right)$ as compared to application of organic and inorganic fertilizers alone. Significantly increased the growth and yield attributes of cowpea might be due to increased availability of nitrogen, phosphorus, potassium and other nutrients from continuous mineralization of compost throughout the crop growth period. The application of FYM combined with 50 per cent NPK had significant residual effect on pod yield of cowpea over inorganic fertilizer alone (Dubey and Verma, 1999). Similar results were reported by Sukumari (1997) and Joshi et al., (2016).

\section{Yield of cowpea}

A significantly higher grain yield $(13.33 \mathrm{~g}$ pot $\left.^{-1}\right)$ was recorded in $\mathrm{T}_{5}(100 \% \mathrm{NPK}+$ segregated compost) which was found on par with $\mathrm{T}_{6}(100 \%$ NPK + unsegregated compost) recorded $13.28 \mathrm{~g} \mathrm{pot}^{-1}$ grain yield (Table 2). Application of FYM alone (10 t $\mathrm{ha}^{-1}$ ) recorded the lowest grain yield of 11.95 $\mathrm{g} \mathrm{pot}^{-1}$. The application of 100 per cent NPK + segregated compost produced 10.35 and 9.30 per cent yield increment over the application of FYM @ $10 \mathrm{t} \mathrm{ha}^{-1}$ and 100 per cent NPK alone, respectively. The similar trend was follow in case of haulm yield of residual cowpea.

The grain yield pot $^{-1}$ increased by the application of 100 per cent NPK + segregated urban solid waste compost might be due to its ability to make nutrients (macro and micronutrients) more readily available to crop plants upon mineralization and supply of the nutrient to the crop throughout the vegetation period of crop.Combined application of FYM and poultry manure with 50 per cent NPK significantly increased the grain and haulm 
yield of residual cowpea as documented by Dubey and Verma (1999). Iqbal et al., (2015) also reported that an optimum combination of organic as well as inorganic fertilizers has the potential to increase the forage yield of maize.

\section{Uptake of major nutrients by grain and haulm of cowpea}

The application of segregated compost along with 100 per cent NPK increased the uptake of nutrients by grain and haulm of cowpea (Table 3 and 4). Significantly higher uptake of nitrogen by grain and haulm of cowpea having values of $0.54 \mathrm{~g}$ plant $^{-1}$ and $0.173 \mathrm{~g}$ plant ${ }^{-1}$, respectively was recorded in $\mathrm{T}_{5}(100$ $\% \mathrm{NPK}+$ segregated compost) on par with $\mathrm{T}_{6}$ (100\% N + unsegregated compost) recorded $0.52 \mathrm{~g} \mathrm{plant}^{-1}$ and $0.172 \mathrm{~g} \mathrm{plant}^{-1}$, respectively. The uptake of phosphorus by grain $(0.057 \mathrm{~g}$ plant $\left.{ }^{-1}\right)$ and haulm $\left(0.032 \mathrm{~g} \mathrm{plant}^{-1}\right)$ of cowpea significantly higher in the treatment $\mathrm{T}_{5}(100$ $\% \mathrm{NPK}+$ segregated compost) on par with $\mathrm{T}_{6}$ (100\% $\mathrm{N}+$ unsegregated compost) which recorded $0.056 \mathrm{~g} \mathrm{plant}^{-1}$ and $0.031 \mathrm{~g}$ plant $^{-1}$, respectively. Similarly, significantly higher uptake of potassium by grain and haulm of cowpea having values of $0.45 \mathrm{~g} \mathrm{plant}^{-1}$ and $0.158 \mathrm{~g}$ plant $^{-1}$, respectively was recorded in $\mathrm{T}_{5}(100 \% \mathrm{NPK}+$ segregated compost $)$.

Table.1 Chemical composition of segregated, unsegregated urban solid waste compost and Farmyard Manure (FYM)

\begin{tabular}{|c|c|c|c|}
\hline Parameters & $\begin{array}{c}\text { Farmyard } \\
\text { manure (FYM) }\end{array}$ & $\begin{array}{l}\text { Segregated urban } \\
\text { solid waste } \\
\text { compost }\end{array}$ & $\begin{array}{l}\text { Unsegregated urban } \\
\text { solid waste compost }\end{array}$ \\
\hline $\mathrm{pH}(1: 10)$ & 7.2 & 7.35 & 7.84 \\
\hline $\mathrm{EC}\left(\mathrm{dSm}^{-1}\right)$ & 1.22 & 1.12 & 1.51 \\
\hline $\begin{array}{l}\text { Organic carbon } \\
(\%)\end{array}$ & 17.77 & 29.16 & 24.17 \\
\hline $\mathrm{C}: \mathrm{N}$ ratio & 29.01 & 17.78 & 19.18 \\
\hline $\mathrm{N}(\%)$ & 0.61 & 1.64 & 1.22 \\
\hline $\mathrm{P}(\%)$ & 0.18 & 0.15 & 0.32 \\
\hline $\mathrm{K}(\%)$ & 0.52 & 1.11 & 0.91 \\
\hline $\mathrm{Ca}(\%)$ & 0.68 & 1.47 & 0.95 \\
\hline $\operatorname{Mg}(\%)$ & 0.27 & 0.74 & 0.56 \\
\hline $\mathrm{S}(\%)$ & 0.21 & 0.76 & 0.64 \\
\hline $\mathrm{Zn}\left(\mathrm{mg} \mathrm{kg}^{-1}\right)$ & 13.86 & 118.07 & 143.17 \\
\hline $\mathrm{Cu}\left(\mathrm{mg} \mathrm{kg}^{-1}\right)$ & 2.2 & 42.11 & 44.23 \\
\hline $\mathrm{Fe}\left(\mathrm{mg} \mathrm{kg}^{-1}\right)$ & 520.3 & 3529.11 & 3604 \\
\hline $\operatorname{Mn}\left(\mathrm{mg} \mathrm{kg}^{-1}\right)$ & 38.12 & 350.67 & 366.33 \\
\hline $\mathrm{Ni}\left(\mathrm{mg} \mathrm{kg}^{-1}\right)$ & 18.21 & 12.75 & 23.42 \\
\hline $\mathrm{Cd}\left(\mathrm{mg} \mathrm{kg}^{-1}\right)$ & ND & ND & ND \\
\hline $\mathrm{Pb}\left(\mathrm{mg} \mathrm{kg}^{-1}\right)$ & ND & 23.87 & 43.62 \\
\hline $\mathrm{Cr}\left(\mathrm{mg} \mathrm{kg}^{-1}\right)$ & ND & 12.53 & 21.34 \\
\hline
\end{tabular}


Table.2 Residual effect of segregated and unsegregated urban solid waste composts on growth of cowpea

\begin{tabular}{|c|c|c|c|c|c|c|c|c|}
\hline \multirow[t]{2}{*}{ Treatments } & \multicolumn{2}{|c|}{$\begin{array}{l}\text { Plant height } \\
(\mathrm{cm})\end{array}$} & \multirow{2}{*}{$\begin{array}{l}\text { No. of } \\
\text { leaves } \\
\text { plant }^{-1}\end{array}$} & \multirow{2}{*}{$\begin{array}{l}\text { No. of } \\
\text { branches } \\
\text { plant }^{-1}\end{array}$} & \multirow{2}{*}{$\begin{array}{c}\text { Root } \\
\text { biomass } \\
\text { plant }^{-1} \\
(\mathrm{~g})\end{array}$} & \multirow{2}{*}{$\begin{array}{c}\text { Leaf area } \\
\text { Plant }^{-1} \\
\left(\mathrm{~cm}^{2}\right)\end{array}$} & \multirow[t]{2}{*}{$\begin{array}{l}\text { Nodule } \\
\text { Number }\end{array}$} & \multirow{2}{*}{$\begin{array}{l}\text { Pod } \\
\text { length } \\
(\mathrm{cm})\end{array}$} \\
\hline & $\begin{array}{c}30 \\
\text { DAS }\end{array}$ & $\begin{array}{c}90 \\
\text { DAS }\end{array}$ & & & & & & \\
\hline $\mathrm{T}_{1}$ & 16.33 & 37.50 & 22.67 & 7.67 & 0.81 & 276.70 & 24.33 & 15.00 \\
\hline $\mathrm{T}_{2}$ & 15.25 & 35.83 & 20.17 & 6.33 & 0.74 & 262.72 & 20.67 & 13.79 \\
\hline $\mathrm{T}_{3}$ & 15.58 & 36.08 & 21.00 & 6.50 & 0.76 & 248.18 & 21.00 & 13.83 \\
\hline $\mathrm{T}_{4}$ & 14.79 & 35.50 & 19.50 & 5.83 & 0.73 & 234.65 & 18.00 & 12.93 \\
\hline $\mathrm{T}_{5}$ & 17.25 & 38.83 & 23.00 & 7.83 & 0.82 & 284.82 & 28.67 & 15.20 \\
\hline $\mathrm{T}_{6}$ & 16.58 & 38.00 & 22.83 & 7.67 & 0.81 & 276.51 & 27.00 & 15.00 \\
\hline $\mathrm{T}_{7}$ & 16.33 & 37.00 & 22.67 & 6.83 & 0.80 & 271.29 & 24.00 & 14.56 \\
\hline $\mathrm{T}_{8}$ & 15.83 & 36.25 & 22.50 & 6.67 & 0.79 & 252.95 & 23.00 & 14.27 \\
\hline $\mathrm{T}_{9}$ & 15.42 & 36.17 & 21.00 & 6.50 & 0.77 & 248.00 & 22.67 & 14.10 \\
\hline $\mathrm{T}_{10}$ & 15.67 & 35.58 & 19.67 & 5.00 & 0.75 & 240.14 & 18.33 & 13.17 \\
\hline $\mathrm{T}_{11}$ & 16.25 & 36.33 & 20.50 & 5.67 & 0.76 & 246.87 & 19.33 & 14.53 \\
\hline S. Em \pm & 0.70 & 1.62 & 0.56 & 0.25 & 0.03 & 1.20 & 1.67 & 0.52 \\
\hline $\mathrm{CD}(5 \%)$ & NS & NS & 1.77 & 0.80 & NS & 3.80 & 5.28 & 1.63 \\
\hline
\end{tabular}

Table.3 Residual effects of segregated and unsegregated urban solid waste composts on yield and yield parameters of cowpea

\begin{tabular}{ccccccc}
\hline Treatments & $\begin{array}{c}\text { Number of } \\
\text { pods plant }^{-1}\end{array}$ & $\begin{array}{c}\text { Number } \\
\text { of } \\
\text { grainpod }^{-}\end{array}$ & $\begin{array}{c}\text { Test } \\
\text { weight } \\
(\mathrm{g})\end{array}$ & $\begin{array}{c}\text { Pod } \\
\text { weight }_{\text {plant }}^{-1} \\
(\mathrm{~g})\end{array}$ & $\begin{array}{c}\text { Grain } \\
\text { yield pot }^{-1} \\
(\mathrm{~g})\end{array}$ & $\begin{array}{c}\text { Haulm } \\
\text { yield }^{-(\mathrm{g}} \\
\left.\text { pot }^{-1}\right)\end{array}$ \\
\hline $\mathrm{T}_{1}$ & 16.00 & 10.40 & 11.62 & 8.51 & 13.28 & 12.13 \\
$\mathrm{~T}_{2}$ & 15.67 & 9.37 & 10.63 & 7.05 & 12.42 & 10.52 \\
$\mathrm{~T}_{3}$ & 14.33 & 8.63 & 10.64 & 7.45 & 12.19 & 10.82 \\
$\mathrm{~T}_{4}$ & 13.67 & 7.03 & 10.22 & 5.31 & 11.95 & 10.34 \\
$\mathrm{~T}_{5}$ & 16.67 & 11.23 & 11.79 & 9.19 & 13.33 & 12.17 \\
$\mathrm{~T}_{6}$ & 16.33 & 11.00 & 11.73 & 8.96 & 13.20 & 12.18 \\
$\mathrm{~T}_{7}$ & 15.33 & 9.90 & 11.55 & 7.87 & 13.12 & 12.00 \\
$\mathrm{~T}_{8}$ & 15.00 & 8.90 & 10.93 & 8.41 & 12.30 & 11.80 \\
$\mathrm{~T}_{9}$ & 14.33 & 8.23 & 10.84 & 6.81 & 12.12 & 11.14 \\
$\mathrm{~T}_{10}$ & 13.33 & 7.93 & 10.54 & 5.77 & 11.94 & 10.98 \\
$\mathrm{~T}_{11}$ & 14.33 & 8.43 & 10.81 & 5.81 & 12.09 & 10.71 \\
\hline $\mathrm{S} . \mathrm{Em} \pm$ & 0.38 & 0.34 & 0.08 & 0.56 & 0.10 & 0.83 \\
\hline $\mathrm{CD}(5 \%)$ & 1.22 & 1.07 & 0.25 & 1.76 & 0.34 & $\mathrm{NS}$ \\
\hline
\end{tabular}


Table.4 Residual effect of segregated and unsegregated urban solid waste composts on major, secondary and macronutrient uptake by grain of cowpea

\begin{tabular}{|c|c|c|c|c|c|c|c|c|c|c|}
\hline \multirow[t]{2}{*}{ Treatments } & \multicolumn{6}{|c|}{$\begin{array}{l}\text { Uptake of major and secondary nutrients by grain of } \\
\text { cowpea }\left(\mathrm{g} \text { plant }{ }^{-1}\right)\end{array}$} & \multicolumn{4}{|c|}{$\begin{array}{l}\text { Uptake of micronutrients by } \\
\text { grain of cowpea }\left(\mathrm{mg} \mathrm{plant}^{-1}\right)\end{array}$} \\
\hline & $\mathrm{N}$ & $\mathrm{P}$ & $\mathrm{K}$ & $\mathrm{Ca}$ & $\mathrm{Mg}$ & $\mathrm{S}$ & $\mathrm{Cu}$ & $\mathrm{Mn}$ & $\mathrm{Zn}$ & $\mathrm{Fe}$ \\
\hline $\mathrm{T}_{1}$ & 0.52 & 0.053 & 0.41 & 0.064 & 0.032 & 0.036 & 0.32 & 0.99 & 0.45 & 2.17 \\
\hline $\mathrm{T}_{2}$ & 0.43 & 0.047 & 0.35 & 0.049 & 0.026 & 0.027 & 0.25 & 0.78 & 0.37 & 1.77 \\
\hline $\mathrm{T}_{3}$ & 0.42 & 0.045 & 0.36 & 0.046 & 0.023 & 0.026 & 0.30 & 0.85 & 0.40 & 1.86 \\
\hline $\mathrm{T}_{4}$ & 0.28 & 0.039 & 0.28 & 0.033 & 0.019 & 0.021 & 0.19 & 0.56 & 0.24 & 1.47 \\
\hline $\mathrm{T}_{5}$ & 0.54 & 0.057 & 0.45 & 0.072 & 0.038 & 0.040 & 0.34 & 0.99 & 0.46 & 2.34 \\
\hline $\mathrm{T}_{6}$ & 0.52 & 0.056 & 0.43 & 0.067 & 0.037 & 0.037 & 0.39 & 1.01 & 0.51 & 2.41 \\
\hline $\mathrm{T}_{7}$ & 0.50 & 0.052 & 0.39 & 0.062 & 0.032 & 0.035 & 0.32 & 0.88 & 0.41 & 2.02 \\
\hline $\mathrm{T}_{8}$ & 0.46 & 0.047 & 0.37 & 0.055 & 0.029 & 0.029 & 0.34 & 0.88 & 0.42 & 1.98 \\
\hline $\mathrm{T}_{9}$ & 0.45 & 0.045 & 0.35 & 0.053 & 0.026 & 0.026 & 0.29 & 0.72 & 0.32 & 1.66 \\
\hline $\mathrm{T}_{10}$ & 0.40 & 0.041 & 0.34 & 0.038 & 0.021 & 0.022 & 0.23 & 0.60 & 0.25 & 1.53 \\
\hline $\mathrm{T}_{11}$ & 0.43 & 0.043 & 0.35 & 0.043 & 0.022 & 0.024 & 0.27 & 0.67 & 0.28 & 1.60 \\
\hline S. Em \pm & 0.006 & 0.0004 & 0.007 & 0.001 & 0.001 & 0.0009 & 0.006 & 0.01 & 0.009 & 0.18 \\
\hline $\mathrm{CD}(5 \%)$ & 0.020 & 0.0015 & 0.024 & 0.005 & 0.003 & 0.0029 & 0.020 & 0.03 & 0.030 & 0.57 \\
\hline
\end{tabular}

Table.5 Residual effect of segregated and unsegregated urban solid waste composts on major, secondary and micronutrient uptake by haulm of cowpea

\begin{tabular}{ccccccccccc}
\hline Treatments & \multicolumn{4}{c}{$\begin{array}{c}\text { Uptake of major and secondary nutrients by } \\
\end{array}$} & \multicolumn{4}{c}{ haulm of cowpea $\left(\mathrm{g}\right.$ plant $\left.{ }^{-1}\right)$} & \multicolumn{4}{c}{$\left.\begin{array}{c}\text { Uptake of micronutrients by } \\
\text { haulm of cowpea }(\mathrm{mg} \text { plant }\end{array}{ }^{-1}\right)$} \\
\cline { 2 - 12 } & $\mathrm{N}$ & $\mathrm{P}$ & $\mathrm{K}$ & $\mathrm{Ca}$ & $\mathrm{Mg}$ & $\mathrm{S}$ & $\mathrm{Cu}$ & $\mathrm{Mn}$ & $\mathrm{Zn}$ & $\mathrm{Fe}$ \\
\hline $\mathrm{T}_{1}$ & 0.169 & 0.031 & 0.153 & 0.106 & 0.038 & 0.059 & 0.25 & 1.19 & 0.48 & 2.64 \\
$\mathrm{~T}_{2}$ & 0.140 & 0.026 & 0.118 & 0.064 & 0.021 & 0.040 & 0.14 & 0.93 & 0.39 & 1.37 \\
$\mathrm{~T}_{3}$ & 0.143 & 0.027 & 0.123 & 0.069 & 0.023 & 0.044 & 0.19 & 1.03 & 0.44 & 2.43 \\
$\mathrm{~T}_{4}$ & 0.130 & 0.024 & 0.107 & 0.061 & 0.017 & 0.034 & 0.11 & 0.64 & 0.31 & 1.01 \\
$\mathrm{~T}_{5}$ & 0.173 & 0.032 & 0.158 & 0.125 & 0.042 & 0.062 & 0.26 & 1.24 & 0.57 & 2.60 \\
$\mathrm{~T}_{6}$ & 0.172 & 0.031 & 0.155 & 0.118 & 0.038 & 0.059 & 0.30 & 1.41 & 0.60 & 3.37 \\
$\mathrm{~T}_{7}$ & 0.167 & 0.030 & 0.145 & 0.100 & 0.034 & 0.054 & 0.21 & 1.12 & 0.51 & 2.28 \\
$\mathrm{~T}_{8}$ & 0.161 & 0.030 & 0.140 & 0.082 & 0.033 & 0.052 & 0.24 & 1.28 & 0.55 & 2.82 \\
$\mathrm{~T}_{9}$ & 0.151 & 0.028 & 0.124 & 0.076 & 0.029 & 0.046 & 0.18 & 0.88 & 0.41 & 1.85 \\
$\mathrm{~T}_{10}$ & 0.142 & 0.026 & 0.115 & 0.066 & 0.022 & 0.037 & 0.13 & 0.72 & 0.35 & 1.32 \\
$\mathrm{~T}_{11}$ & 0.145 & 0.026 & 0.125 & 0.075 & 0.029 & 0.039 & 0.15 & 0.78 & 0.36 & 1.55 \\
\hline $\mathrm{S} . \mathrm{Em} \pm$ & 0.01 & 0.002 & 0.011 & 0.008 & 0.008 & 0.003 & 0.012 & 0.07 & 0.03 & 0.16 \\
\hline $\mathrm{CD}(5 \%)$ & 0.03 & 0.006 & 0.034 & 0.025 & 0.002 & 0.011 & 0.040 & 0.24 & 0.10 & 0.53 \\
\hline
\end{tabular}

The increase in nitrogen content may be due to the complimentary effect of organics upon mineralization increased nitrogen availability in the soil results in uptake by cowpea. This is in agreement with the findings of Narayana Reddy and Krishnaiah (1999) who reported 
that with the application one tonne of organic manure about one third of total nitrogen is available to first crop and rest of nitrogen is available to the succeeding crop as residual effect. The results are in accord with the findings of Rostami et al., (2012) and Mohammadreza et al., (2010) reported an increase nitrogen content and uptake in soyabean with the application of municipal solid waste compost. The increase in $\mathrm{P}$ uptake in cowpea haulm in treatment $\mathrm{T}_{5}(100 \% \mathrm{NPK}$ + segregated compost) might be due to larger quantities of $\mathrm{P}$ supplied through inorganics as well as organics sources viz., segregated, unsegregated urban solid waste compost and FYM and enhanced availability due to mineralization of organic sources. Narayana Reddy and Krishnaiah (1999) also reported that with the application one tonne of organic manure about half of total $\mathrm{P}$ is available to first crop and rest of $P$ is available to the succeeding crop. The increased uptake of potassium may be attributed to more accessibility of the nutrients from the added organic and inorganic fertilizers and the solubility action of organic acids produced during the decomposition of organic materials, thus resulting in more release of both of native and applied $\mathrm{K}$ nutrients (Bellaki et al., 1997).

\section{Uptake of secondary nutrients by grain and haulm of cowpea}

The treatment $\mathrm{T}_{5}(100 \% \mathrm{NPK}+$ segregated compost) showed the superiority over other treatments for the uptake of $\mathrm{Ca}, \mathrm{Mg}$ and $\mathrm{S}$ (Table 3 and 4). Significantly higher uptake of calcium by grain and haulm of cowpea having values of $0.072 \mathrm{~g} \mathrm{plant}^{-1}$ and $0.125 \mathrm{~g}$ plant $^{-1}$, respectively was recorded in $T_{5}(100$ $\% \mathrm{NPK}+$ segregated compost) on par with $\mathrm{T}_{6}$ (100\% $\mathrm{N}+$ unsegregated compost) which recorded $0.067 \mathrm{~g} \mathrm{plant}^{-1}$ and $0.061 \mathrm{~g} \mathrm{plant}^{-1}$, respectively. Significantly higher uptake of magnesium by grain and haulm of cowpea having values of $0.038 \mathrm{~g} \mathrm{plant}^{-1}$ and $0.042 \mathrm{~g}$ plant $^{-1}$, respectively was recorded in $\mathrm{T}_{5}(100$ $\%$ NPK + segregated compost). Significantly higher uptake of sulphur by grain and haulm of cowpea having values of $0.040 \mathrm{~g} \mathrm{plant}^{-1}$ and $0.062 \mathrm{~g} \mathrm{plant}^{-1}$, respectively was recorded in $\mathrm{T}_{5}(100 \% \mathrm{NPK}+$ segregated compost) on par with $\mathrm{T}_{6}(100 \% \mathrm{~N}+$ unsegregated compost) which recorded $0.037 \mathrm{~g} \mathrm{plant}^{-1}$ and 0.059 g plant $^{-1}$, respectively.

Calcium and magnesium uptake was significantly higher in cowpea haulm which might be due to the higher calcium and magnesium content in segregated urban solid waste compost that release $\mathrm{Ca}$ and $\mathrm{Mg}$ nutrients into soil solution as a result of mineralization of applied organics as reported by Srikanth (1997). Sunitha et al., (2010) reported that availability of secondary nutrient status ( $\mathrm{Ca}$ and $\mathrm{Mg}$ ) concentration and uptake of nutrients were significantly influenced by native as well as the applied sources. The increase in sulphur uptake may be attributed to residualeffect of applied organic which might have resulted in slow and steady release of sulphur from native as well as the applied sources. The results are in accordance with the findings of Math (2001).

\section{Uptake of micronutrients by grain and haulm of cowpea}

The uptake of micronutrients by grain and haulm of cowpea have significantly influenced by residual treatments (Table 3 and 4). Significantly higher uptake of $\mathrm{Fe}, \mathrm{Cu}$, $\mathrm{Mn}$ and $\mathrm{Zn}$ by grain $(2.41,0.39,1.01$ and $\left.0.51 \mathrm{~g} \mathrm{plant}^{-1}\right)$ and haulm $(3.37,0.30,1.41$ and $0.60 \mathrm{mg} \mathrm{plant}^{-1}$ ) of cowpea, respectively was recorded in treatment $\mathrm{T}_{6}(100 \% \mathrm{~N}+$ unsegregated compost) (Table 5).

The treatment which received of 100 per cent NPK + unsegregated urban solid waste compost@10 t ha ${ }^{-1}$ recorded significantly higher micronutrient uptake by grain and 
haulm of cowpea. Increase in uptake might be due to application of organics enhanced microbial population in soil which in turn released chelating agent's leads to increase in concentration of micronutrients in cowpea. Similar findings were by Rangaraj et al., (2007). Davari and Sharma (2010) indicated that application of FYM has significantly increased the uptake of $\mathrm{Zn}, \mathrm{Fe}, \mathrm{Mn}$ and $\mathrm{Cu}$ by rice.

In conclusion, the application of urban solid waste compost and inorganics to finger millet crop resulted into a residual effect on cowpea crop. Treatment $\left(\mathrm{T}_{5}\right)$ which is comprised of 100 per cent NPK + segregated urban solid waste compost @ $10 \mathrm{t} \mathrm{ha}^{-1}$ significantly increased the yield and uptake of nutrients like $\mathrm{N}, \mathrm{P}, \mathrm{K}, \mathrm{Ca}, \mathrm{Mg}$ and $\mathrm{S}$ by cowpea grain and haulm. However, Treatment $\mathrm{T}_{6}$ (100 per cent NPK + unsegregated urban solid waste compost @10 t ha ${ }^{-1}$ ) recorded higher uptake of micronutrients viz., $\mathrm{Mn}, \mathrm{Fe}, \mathrm{Cu}$ and $\mathrm{Zn}$ as compared to inorganic treatment alone.

\section{Acknowledgement}

Authors would like to show our gratitude to the Dr. Raj Mukhopadhyay for sharing their pearls of wisdom with us during the course of this research, and we thank him for their insights regarding the concerned subject.

\section{References}

Bellaki, M.A., Badanur, V.P. and Setty, R.A. 1997. Influence of long term use of organic and inorganic sources of nutrients on crop yield and nutrient uptake by irrigated paddy. Karnataka Journal of Agricultural Sciences, 10: 659-663.

Black, C.A. 1965. Methods of soil analysis part II. Chemical and microbial properties No. 9 in the series of Agronomy. American Society of
Agronomy. Inc., Maadison, Wisconsin, USA.

Davari, M.R. and Sharma, S.N. 2010. Effect of different combinations of organic materials and bio-fertilizers on productivity, grain and economics in organic farming of basmati rice (Oryza sativa L.). Indian Journal of Agronomy, 55(4): 290-294.

Dubey, R.P. and Verma, B.S. 1999. Integrated nutrient management in rice (Oryza sativa)-rice-cowpea (Vigna unguiculata) sequence under humid tropical Andaman Islands. Indian Journal of Agronomy, 44(1):73-76.

Eghball, B., Ginting, D. and Gilley, J.E. 2004. Residual effects of manure and compost applications on corn production and soil properties. Agronomy Journal, 96(2): 442-447.

Iqbal, M.A., Iqbal, A., Ahmad, Z., Raza, A. andNabeel, F. 2015. Overviewing forage maize yield and quality attributes enhancement with plant nutrition management world. Journal of Agricultural Sciences, 11(3): 128-134.

Jackson, M.L. 1973. Soil chemical analysis. Prentice hall of India Pvt. Ltd. New Delhi.

Joshi, D., Gediya, K.M., Patel, J.S., Birari, M.M. and Gupta, S. 2016. Effect of organic manures on growth and yield of summer cowpea [Vigna unguiculata (L.) Walp] under middle Gujarat conditions. Agricultural Science Digest, 36 (2): 134-137.

Lindsay, W.L. and Norwell, W.A. 1978. Development of a DTPA soil test for zinc, iron, manganese and copper. Soil Science Society of America Journal, 42: 421-428.

Math, K.K. 2001. Effect of nitrogen substitution through organics on soil health and crop yields in wheatsoyabean cropping system. Ph. D. Thesis, Univ. Agric. Sci., Dharwad. 
Mohammadreza, M., Zohre, A., Sevda, A. and Kobra, K. 2010. Fertilization of soybean plants with municipal solid waste compost under leaching and nonleaching conditions. American-Eurasian Journal of Agricultural and Environmental Sciences, 8(1): 55-59.

Narayana Reddy, M. and Krishnaiah, K. 1999. Integrated nutrient management for sustainable rice production. Tech. Bull., Directorate of Rice Research (ICAR), Hyderabad-30 (AP).

Nigussie, A., Kuyper, T.W. and De Neergaard, A. 2015. Agricultural waste utilisation strategies and demand for urban waste compost: evidence from smallholder farmers in Ethiopia. Waste Management, 44: 82-93.

Rangaraj, T., Somasundaram, E., Mohamed Amanullah, M., Thirumurugan, V., Ramesh, S. and Ravi, S. 2007. Effect of agro-industrial wastes on soil properties and yield of irrigated finger millet (Eleusine coracana (L). Gaertn) in coastal soil. Research Journal Agricultural and Biological Sciences, 3(3): 153-156.

Rostami, S.V., Piradashti, H., Bahmanyar, M.A. and Alaleh Motaghian 2012. Response of soyabean (Glycine max L.) yield and nutrient uptake in three consecutive years application of municipal solid waste compost. International Journal of Agriculture Crop Science, 4(8): 468-473.

Srikanth, K. 1997. Enrichment of compost and its effect on soil properties and crop growth. Ph.D. Thesis, University of Agricultural Sciences, Bangalore.

Sukumari, P. 1997. Integrated nutrient management in soyabean [Glycine max. (L) Merill] in Vertisols of northern transitional zone of Karnataka. Ph.D Thesis, University of Agricultural Sciences, Dharwad.

Sundaraj, N., Nagaraju, S., Venkataramu, M.N. and Jagannath, M.L. 1972. Design and analysis of field experiments. University of Agricultural Sciences. Bangalore.

Sunitha, B.P., Prakasha, H.C and Gurumurthy, K.T. 2010. Influence of organics, inorganics and their combination on availability, content and uptake of secondary nutrients by rice crop (oryza sativa L.) in bhadra command, Karnataka. Mysore Journal of Agricultural Sciences, 44(3): 509-516

Yadav, V.P.S. 1986. Future challenges of agriculture in India. Indian Agriculture, 30: $1-20$.

\section{How to cite this article:}

Roohi, H.C. Prakasha and Meena, H.M. 2018. Residual Effect of Segregated and Unsegregated Urban Solid Waste Compost on Yield and Nutrient Uptake by Cowpea (Vigna unguiculata L.). Int.J.Curr.Microbiol.App.Sci. 7(08): 2028-2336. doi: https://doi.org/10.20546/ijcmas.2018.708.234 